medRxiv preprint doi: https://doi.org/10.1101/2020.12.03.20243113; this version posted December 4, 2020. The copyright holder for this preprint (which was not certified by peer review) is the author/funder, who has granted medRxiv a license to display the preprint in It is made available under a CC-BY-NC-ND 4.0 International license .

\title{
Systematic review and meta-analysis of the calibration of confidence judgments in individuals with schizophrenia spectrum disorders
}

Martin Rouy ${ }^{1 *}$, Pauline Saliou ${ }^{1}$, Ladislas Nalborczyk ${ }^{2}$, Michael Pereira ${ }^{1}$, Paul Roux ${ }^{3+}$, Nathan Faivre ${ }^{1+}$

\author{
Affiliations \\ Saint-Quentin-En-Yvelines \\ + equal contribution

\section{* Corresponding author:} \\ Martin Rouy \\ Laboratoire de Psychologie et Neurocognition \\ CNRS UMR 5105 \\ UGA BSHM \\ 1251 Avenue Centrale \\ 38058 Grenoble Cedex 9 \\ martinrouy03@gmail.com
}

1 Univ. Grenoble Alpes, Univ. Savoie Mont Blanc, CNRS, LPNC, 38000 Grenoble, France

2 Univ. Grenoble Alpes, CNRS, Grenoble INP, GIPSA-lab, 38000 Grenoble, France

3 Service universitaire de psychiatrie d'adulte et d'addictologie du Centre Hospitalier de Versailles; CESP, Equipe DevPsy, INSERM, Université Paris-Saclay et Université de Versailles

Keywords: metacognition, insight, psychosis, schizophrenia, meta-perception, meta-memory

Author Contributions: MR, PS, MP, PR and NF developed the study concept and contributed to the study design. Data selection and extraction were performed by MR and PS. MR, LN and NF analyzed data. MR and NF drafted the paper; all authors provided critical revisions and approved the final version of the paper for submission.

\section{The authors declare no competing interests.}

Acknowledgments: NF has received funding from the European Research Council (ERC) under the European Union's Horizon 2020 research and innovation programme (Grant agreement No. 803122). We thank Mathieu Roger for his help at the beginning of this project. We thank Samuele Cortese and Clément Dondé for their valuable advice.

Data availability statement: bibliographic data and analyses scripts are publicly available: https://gitlab.com/nfaivre/meta_analysis_scz_public 
medRxiv preprint doi: https://doi.org/10.1101/2020.12.03.20243113; this version posted December 4, 2020. The copyright holder for this preprint (which was not certified by peer review) is the author/funder, who has granted medRxiv a license to display the preprint in It is made available under a CC-BY-NC-ND 4.0 International license.

\begin{abstract}
Background: Metacognitive deficits are well documented in schizophrenia spectrum disorders as a decreased capacity to adjust confidence to first-order performance in a cognitive task. Because metacognitive ability directly depends on first-order performance, observed metacognitive deficits might be driven by lower first-order performance. We aimed to determine the extent to which individuals with schizophrenia experience specific deficits when producing confidence judgments and examined whether studies controlling for first-order performance found metacognitive deficits of smaller magnitude.
\end{abstract}

Method: Electronic databases were searched for studies published until April $24^{\text {th }} 2020$. We conducted a Bayesian meta-analysis of 43 studies comparing the calibration of confidence in 1458 individuals with schizophrenia compared to 1337 matched controls. Group analyses and meta-regressions quantified how metacognitive deficits depended on task performance, cognitive domains, clinical severity, and antipsychotic dosage.

Outcomes: We found a global metacognitive deficit in schizophrenia $(\mathrm{g}=-0.57,95 \% \mathrm{Crl}$ $[-0.71,-0.43])$, which was driven by studies which did not equate first-order performance between groups $(\mathrm{g}=-0.64,95 \% \mathrm{Crl}[-0.77,-0.51])$, and inconclusive among controlled-studies $\left(\mathrm{g}=-0.28,95 \% \mathrm{Crl}[-0.63,0.07], \mathrm{BF}_{01}=1.3\right.$ ). Plus, the metacognitive deficit in non-controlled studies was correlated with first-order performance. No correlation was found between metacognitive deficit and clinical features of schizophrenia.

Interpretation: We provide evidence for the existence of a deficit in the calibration of confidence judgments in schizophrenia, which is inflated due to non-equated first-order performance. Thus, efforts should be made to develop experimental protocols accounting for lower first-order performance in schizophrenia. 
medRxiv preprint doi: https://doi.org/10.1101/2020.12.03.20243113; this version posted December 4,2020 . The copyright holder for this preprint (which was not certified by peer review) is the author/funder, who has granted medRxiv a license to display the preprint in It is made available under a CC-BY-NC-ND 4.0 International license .

\section{Introduction}

Metacognition is the ability to monitor and control our own mental processes. Metacognitive deficits are thought to play an important role in schizophrenia spectrum disorders (hereafter: schizophrenia) (Hasson-Ohayon et al., 2018). These deficits are inferred both from subjective structured interviews (Semerari et al., 2003) and objective neuropsychological tasks (Koren et al., 2006), and have been linked to core features of schizophrenia including positive and negative symptoms (McLeod et al., 2014), lack of insight into illness (David et al., 2012), disorganisation (Vohs et al., 2014), functioning (Davies \& Greenwood, 2020), and quality of life (Arnon-Ribenfeld et al., 2017).

Despite numerous studies, no meta-analysis has yet been conducted to examine metacognition in schizophrenia. Here we sought to conduct a systematic review and meta-analysis of neuropsychological measures of metacognitive performance in schizophrenia compared to matched healthy controls. From an experimental perspective, the gold standard to quantify metacognition is to assess how participants perform an experimental task (first-order task) and reflect on their own accuracy via confidence ratings (second-order task). Several studies employing this design have reported lower metacognitive performance in schizophrenia compared to healthy controls across different cognitive domains such as vision (Dietrichkeit et al., 2020; Jia et al., 2020; Moritz et al., 2014), audition (Gaweda \& Moritz, 2019), emotion perception (Kother et al., 2012; Moritz et al., 2012; Pinkham et al., 2018), and memory (Berna et al., 2019; Mayer \& Park, 2012; Moritz \& Woodward, 2006). However, these results are mitigated by recent studies that failed to reveal such metacognitive deficits (Faivre et al., 2019; Powers et al., 2017; Wright et al., 2020). Noticeably these studies controlled for potential group differences in first-order performance, either at the design level through adaptive procedures (Levitt, 1971), or at the metric level through indices of metacognitive performance which are independent from first-order performance (Maniscalco \& Lau, 2012). This is especially important in schizophrenia where cognitive impairments are well documented (Gopal \& Variend, 2005; Heinrichs \& Zakzanis, 1998) and associated with metacognitive deficits (Davies \& Greenwood, 2020). Thus, a putative metacognitive deficit may be specific to second-order processing or merely inherited from a deficit at the first-order level. To determine whether schizophrenia involves specific deficits in the calibration of confidence, we conducted a systematic review followed by a Bayesian meta-analysis on a sample of 43 studies. We hypothesized that metacognitive deficits would be smaller in studies controlling for first-order performance. Following a pre-registered plan, we conducted additional subgroup 
medRxiv preprint doi: https://doi.org/10.1101/2020.12.03.20243113; this version posted December 4 , 2020. The copyright holder for this preprint (which was not certified by peer review) is the author/funder, who has granted medRxiv a license to display the preprint in It is made available under a CC-BY-NC-ND 4.0 International license.

analyses and meta-regressions to explore if metacognitive deficits vary across cognitive domains, severity of schizophrenia symptoms, and antipsychotic dosage.

\section{Methods}

This meta-analysis followed the PRISMA recommendations (Moher et al., 2009). The protocol was registered on PROSPERO (CRD42020188614) on May $26^{\text {th }} 2020$, before data extraction. Inclusion criteria followed the PICO framework.

- Population: individuals with schizophrenia or related disorders (schizoaffective, schizophreniform), as defined by standard diagnostic criteria (DSM-III, DSM-III-R, DSM-IV, DSM-IV-R, DSM-IV-TR, DSM 5, ICD-10).

- Intervention: a computerized or manual experimental task with self-reported confidence judgments as behavioral measures on a confidence scale with more than one trial.

- Comparison: healthy controls.

- Outcome: meta-performance defined as the strength of the relationship between first-order performance (accuracy on a neuropsychological task in perception, memory, executive functions, social cognition, and agency) and confidence in the first-order performance, repeated for each trial. Meta-performance indices included: meta-d', M-Ratio, AUROC2, logistic regression, confidence gap, knowledge corruption index, gamma correlation (for details on these measures, see Fleming \& Lau, 2014).

Search strategy: we retrieved English written preprints and peer-reviewed articles in three databases - Pubmed, Web of Science, Scopus - with the following query applied to the title, abstract and keywords:

(schizophrenia OR schizophrenic OR schizo-affective OR schizoaffective) AND (confident OR confidence OR metacognition OR metacognitive OR "error awareness" OR "error monitoring").

Search was performed on April $24^{\text {th }} 2020$, and no new search before analysis was performed. This query could not identify one article (Powers et al., 2017) previously known by a co-author as it contained non-matching key-words and reported metacognitive performance in supplementary materials. It was manually included in the list of publications. Two authors (MR and PS) screened studies for inclusion in parallel, using Cadima 
medRxiv preprint doi: https://doi.org/10.1101/2020.12.03.20243113; this version posted December 4, 2020. The copyright holder for this preprint (which was not certified by peer review) is the author/funder, who has granted medRxiv a license to display the preprint in It is made available under a CC-BY-NC-ND 4.0 International license.

(https://www.cadima.info; see supplementary information (SI) for details). For each study group, MR and PS extracted the following primary outcomes:

- $\quad$ whether the study controlled for first-order performance between groups (TRUE or FALSE)

- metacognitive performance indices (see above)

- first-order accuracy (\% correct, d')

Depending on the data available, either the mean and standard deviation, or raw statistics ( $\mathrm{t}$ and $\mathrm{F}$ values) were extracted $(\mathrm{SI})$. The following secondary outcomes were extracted:

- cognitive domain

- clinical characteristics including Positive and Negative Syndrome Scale scores (PANSS total, positive, and negative) and antipsychotic dosage (chlorpromazine equivalent).

- age (mean and standard deviation)

- sample size

All analyses were conducted in R. We used the brms package (Bürkner, 2017) based on the Stan framework (Carpenter et al., 2017) to fit a Bayesian meta-analytic multilevel model M1 with fixed and random effects as follows:

$M 1: G_{i} \mid \sigma_{i} \sim$ Intercept + (Intercept | study)

Where $G_{i}$ denotes the Hedge's $g$ effect size of study $i, \sigma_{i}$ denotes the standard error of the effect size from study $\mathrm{i}(\mathrm{SI})$. M1 estimated the overall effect-size of a difference in metacognitive performance between groups (the grand intercept of the model) while accounting for the between-study variability (random intercept per study; see SI for prior definition). To test the existence of a metacognitive deficit in schizophrenia (H1), we compared the estimations of $\mathrm{M} 1$ to the estimations of an alternative model $\mathrm{M} 0$ assuming that metacognitive deficit was inexistent (i.e., fixing the intercept at 0 ; $\mathrm{HO}$ ).

M0: $G_{i} \mid \sigma_{i} \sim 0+($ Intercept $\mid$ study $)$

Results were interpreted based on the relative evidence toward $\mathrm{H} 0$ or $\mathrm{H} 1$ given by the Bayes factor (BF), and the statistics of the posterior distribution (mean and $95 \%$ credible interval, $\mathrm{Crl})$. 
medRxiv preprint doi: https://doi.org/10.1101/2020.12.03.20243113; this version posted December 4,2020 . The copyright holder for this preprint (which was not certified by peer review) is the author/funder, who has granted medRxiv a license to display the preprint in It is made available under a CC-BY-NC-ND 4.0 International license.

Three measures of heterogeneity were computed: the Q-statistic (Card \& Little, 2016), the Q-between statistic (Borenstein et al., 2010), and the $\mathrm{I}^{2}$ index for the percentage of the total variation due to between-studies variability (Higgins \& Thompson, 2002). $I^{2}$ values between 0 and 0.25 suggest small magnitudes of heterogeneity, 0.25 to 0.50 medium magnitudes, and $>0.50$ large magnitudes. Exploratory subgroup analyses and meta-regressions were performed in case of significant Q-between and $I^{2}$ above 25\% (Sterne \& Harbord, 2004). Namely, we assessed the metacognitive deficit amplitude across cognitive domains by fitting a model identical to M1 with the between-study variable "cognitive domains" (perception, memory, others) as an additional categorical covariate. We also explored the correlation between metacognitive performance among patients and continuous variables by adding standardized (z-scores) PANSS scores and chlorpromazine equivalent as meta-regressors to $\mathrm{M} 1$.

To quantify the risk of bias in individual studies, we assessed whether our selection contained extreme effect size values via a leave-one-out sensitivity analysis (SI). We also assessed the risk of bias according to the Newcastle-Ottawa Scale (NOS) adapted for case-control studies (SI). Publication bias was assessed using a funnel plot of observed outcomes against corresponding standard errors (Sterne \& Harbord, 2004). The distribution of p-values was analyzed using the R package dmetar (Harrer et al., 2019) to examine whether some of the studies were subject to p-hacking (p-curve: Simonsohn et al., 2014).

\section{Results}

Our search retrieved 13933 records, 7886 after duplicates removal. 7745 records were excluded after title and abstract screening (Fig.1). Another 99 articles were excluded on the basis of full-text screening, resulting in a selection of 42 articles. One study was excluded because of a strongly deviant outcome identified via a leave-one-out analysis performed on the metacognitive deficit effect-size (SI). Among the 41 remaining articles, two were split into two independent studies as they involved different populations (young versus old: Gaweda et al, 2015; hallucination-prone versus non-hallucination-prone: Powers et al., 2017). The final selection consisted of 43 studies, with a total population of 2795 participants (1458 patients) (Table 1). 
medRxiv preprint doi: https://doi.org/10.1101/2020.12.03.20243113; this version posted December 4, 2020. The copyright holder for this preprint (which was not certified by peer review) is the author/funder, who has granted medRxiv a license to display the preprint in

It is made available under a CC-BY-NC-ND 4.0 International license.

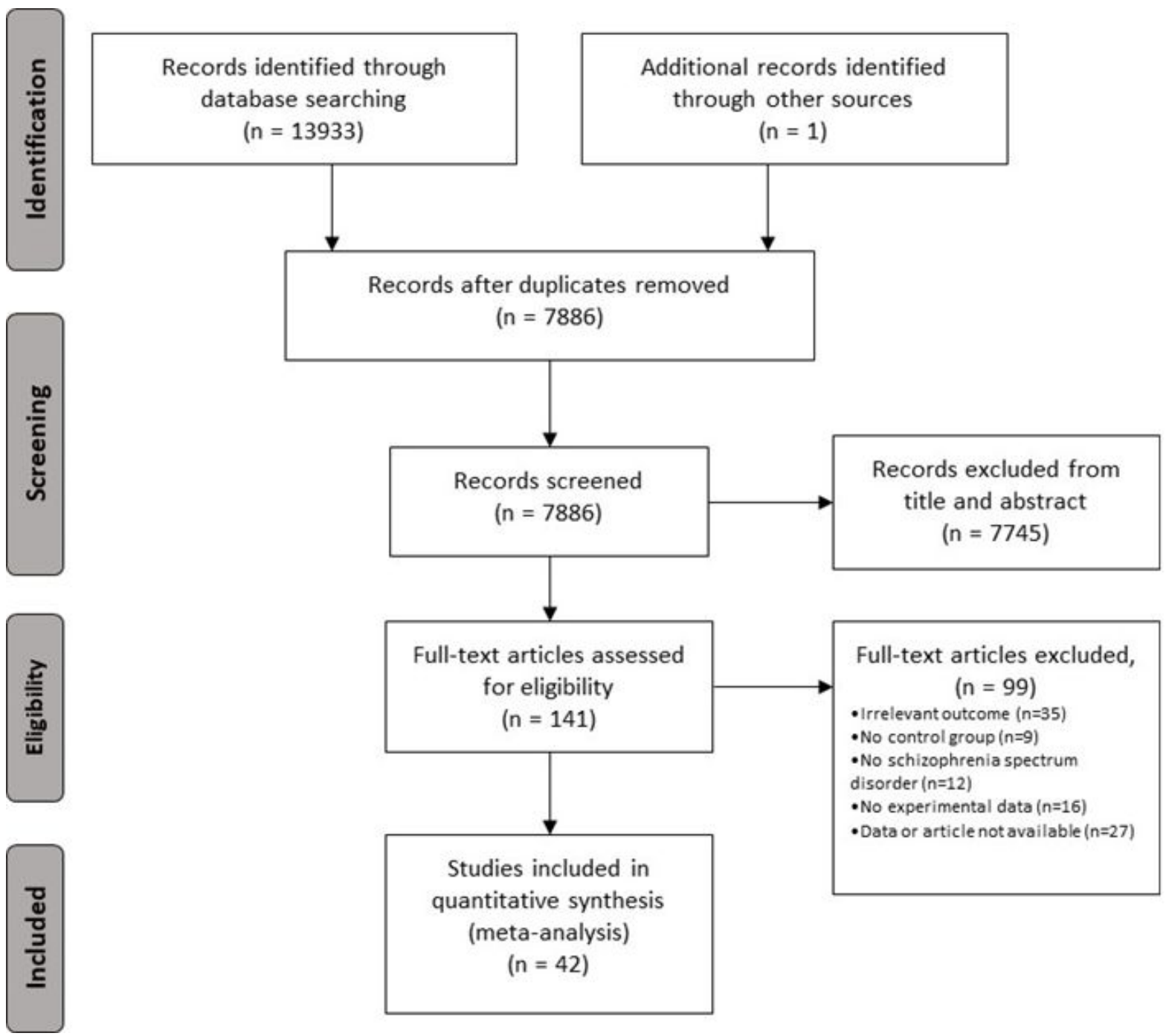

Figure 1: Flow diagram of the selection process.

Our selection included 11 perception (auditory and visual), 27 memory, 4 social cognition, and 1 agency studies. Because of their low number, social cognition and agency studies were regrouped into a generic category termed "others".

The meta-analytic model M1 revealed lower metacognitive performance in the schizophrenia vs. control groups with an effect size $\mathrm{g}=-0.57,95 \% \mathrm{Crl}[-0.71,-0.43]$ (Fig.2). Comparison against the null hypothesis (i.e., absence of a metacognitive deficit in schizophrenia modelled by $\mathrm{M} 0$ ) resulted in a Bayes factor favoring the alternative hypothesis $\mathrm{BF}_{10}=78.58 \times 10^{6}$, indicating extremely strong evidence in favor of a metacognitive deficit in schizophrenia. Of note, this pattern of results was robust to prior variations $(\mathrm{SI})$. 
medRxiv preprint doi: https://doi.org/10.1101/2020.12.03.20243113; this version posted December 4, 2020. The copyright holder for this preprint (which was not certified by peer review) is the author/funder, who has granted medRxiv a license to display the preprint in

\section{$\mathrm{HC} \mathrm{SCZ}$}

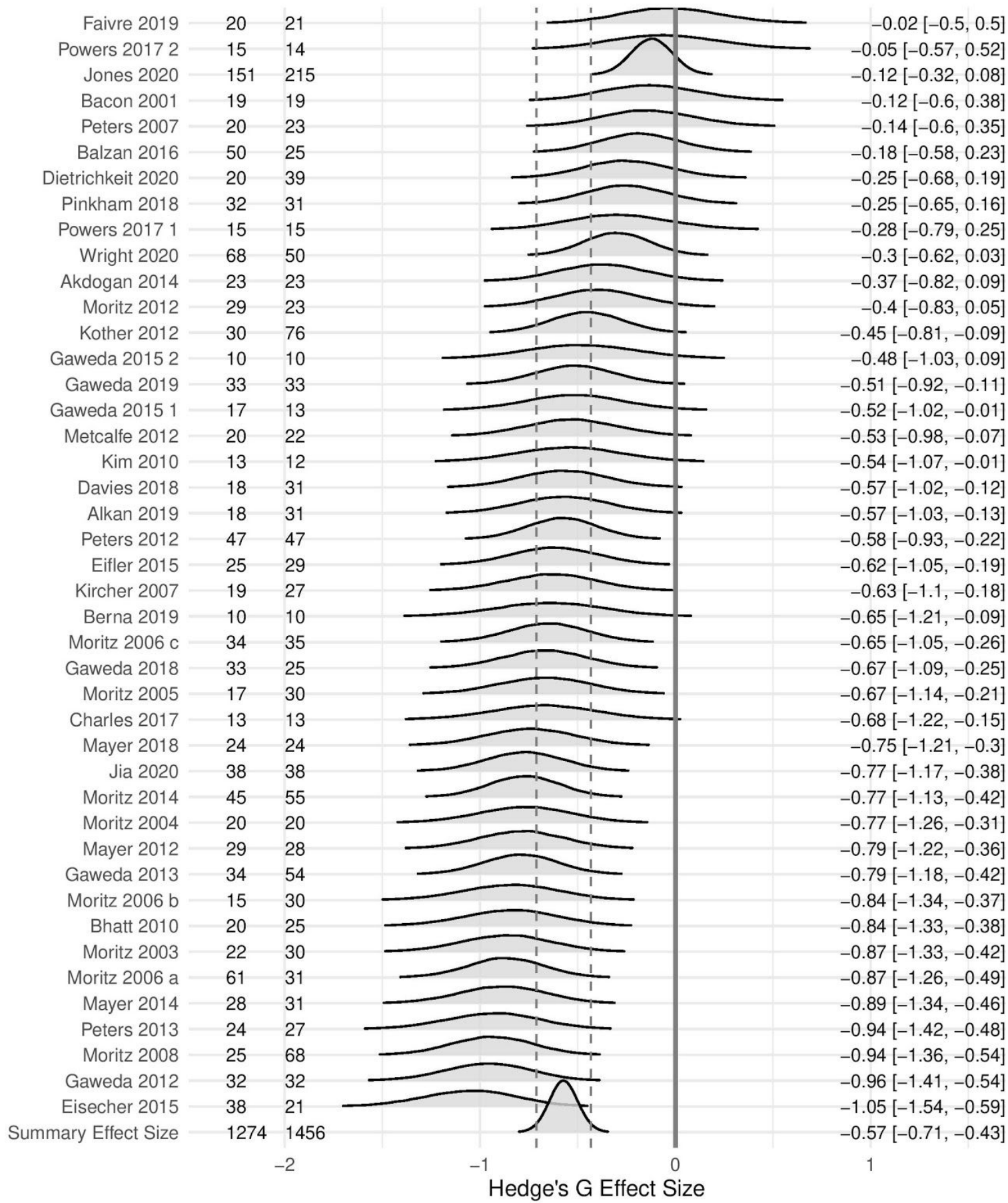

Figure 2: Forest plot of the metacognitive deficit in schizophrenia. Left: Authors with publication year and sample sizes; Middle: posterior distribution of the effect size; Right: mean and $95 \% \mathrm{Crl}$ of the posterior distribution. The summary effect size is displayed on the last row: the solid vertical grey line is centred on zero (i.e., equivalent metacognitive performance between groups), and the dashed vertical lines depict the boundaries of the $95 \% \mathrm{Crl}$.

Heterogeneity analyses produced a significant Q-statistic $(124.6, \mathrm{df}=42, \mathrm{p}<.001)$ and a high amount of heterogeneity $\left(\mathrm{I}^{2}\right.$ statistic $\left.0.66,95 \% \mathrm{Cl}[0.53,0.75]\right)$, suggesting moderator 
medRxiv preprint doi: https://doi.org/10.1101/2020.12.03.20243113; this version posted December 4, 2020. The copyright holder for this preprint (which was not certified by peer review) is the author/funder, who has granted medRxiv a license to display the preprint in It is made available under a CC-BY-NC-ND 4.0 International license .

analyses were appropriate. Because metacognitive performance is known to depend on first-order performance (Maniscalco \& Lau, 2012), and because the latter differed between groups $\left(\mathrm{g}=-0.64,95 \% \mathrm{Crl}[-0.77,-0.51], \mathrm{BF}_{10}=2.11 \times 10^{10}\right)$, we sought to assess whether metacognitive deficits could stem from cognitive impairments that are well documented in schizophrenia (Gopal \& Variend, 2005; Heinrichs \& Zakzanis, 1998). Distinguishing studies controlling for first-order performance $(N=8)$ from those which did not $(N=35)$ revealed a significant moderation effect ( $Q$-between $=5.89$, $\mathrm{df}=1, \mathrm{p}=0.015)$. Thus, we assessed the influence of performance-matching with a model identical to M1 including performance-matching as an additional binary predictor. The sub-group of non-controlled studies had an overall metacognitive deficit of magnitude $\mathrm{g}=-0.63,95 \% \mathrm{Crl}[-0.79,-0.49]$, which was reduced to $\mathrm{g}=-0.28,95 \% \mathrm{Crl}[-0.63,0.07]$ in the sub-group of controlled studies (Fig.3A). Accordingly, the evidence ratio supporting our directional hypothesis that controlling for first-order performance decreases the magnitude of the metacognitive deficit was very strong $\left(\mathrm{BF}_{10}=41\right)(\mathrm{Fig} .3 \mathrm{~B})$. Comparison against the null hypothesis among controlled studies revealed inconclusive evidence in favor of a metacognitive deficit in schizophrenia $\left(\mathrm{BF}_{01}=1.3\right)$. Finally, a positive correlation between cognitive and metacognitive deficits was found among non-controlled studies (SI). Sub-group analyses reduced heterogeneity which however remained significant (SI).
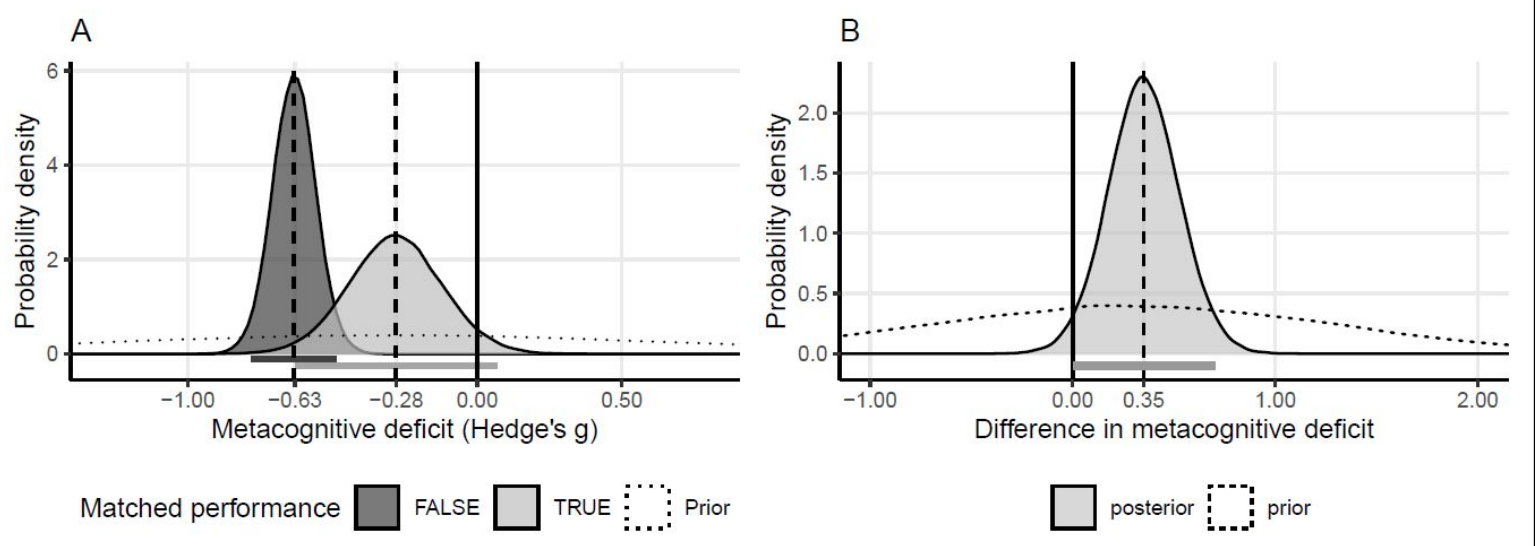

Figure 3: A: Posterior distributions of the metacognitive deficit. Dark gray: non-controlled first-order performance $(n=35)$, Light gray: controlled first-order performance $(n=8)$. B: Posterior distribution of the difference in effect size between studies which did or did not control for first-order performance. In both panels, dotted lines represent the prior distributions, vertical dashed lines the mean posterior values, and the horizontal bars the $95 \% \mathrm{Crl}$.

Next, in line with our pre-registered analysis plan and a significant moderation effect of cognitive domains (Qbetween $=38.2$, df $=2, p<.001$ ), we assessed how metacognitive 
medRxiv preprint doi: https://doi.org/10.1101/2020.12.03.20243113; this version posted December 4, 2020. The copyright holder for this preprint (which was not certified by peer review) is the author/funder, who has granted medRxiv a license to display the preprint in It is made available under a CC-BY-NC-ND 4.0 International license.

deficits varied across cognitive domains (i.e., perception, memory, others). A subgroup analysis revealed the largest metacognitive deficit among memory studies, compared to perception and others. Mean value of the metacognitive deficit in the memory domain $(\mathrm{g}=$ $\left.-0.74,95 \% \mathrm{Crl}[-0.89,-0.58], \mathrm{BF}_{10}=7.74 \times 10^{156}\right)$ was twice higher than in the perception domain $\left(\mathrm{g}=-0.35,95 \% \mathrm{Crl}[-0.63,-0.07], \mathrm{BF}_{10}=4.12\right)$, and three times higher than in other domains ( $\mathrm{g}=-0.26,95 \% \mathrm{Crl}[-0.62,0.09], \mathrm{BF}_{10}=0.39$; see Fig.4 and SI). Sub-group analyses reduced heterogeneity which however remained significant (SI).

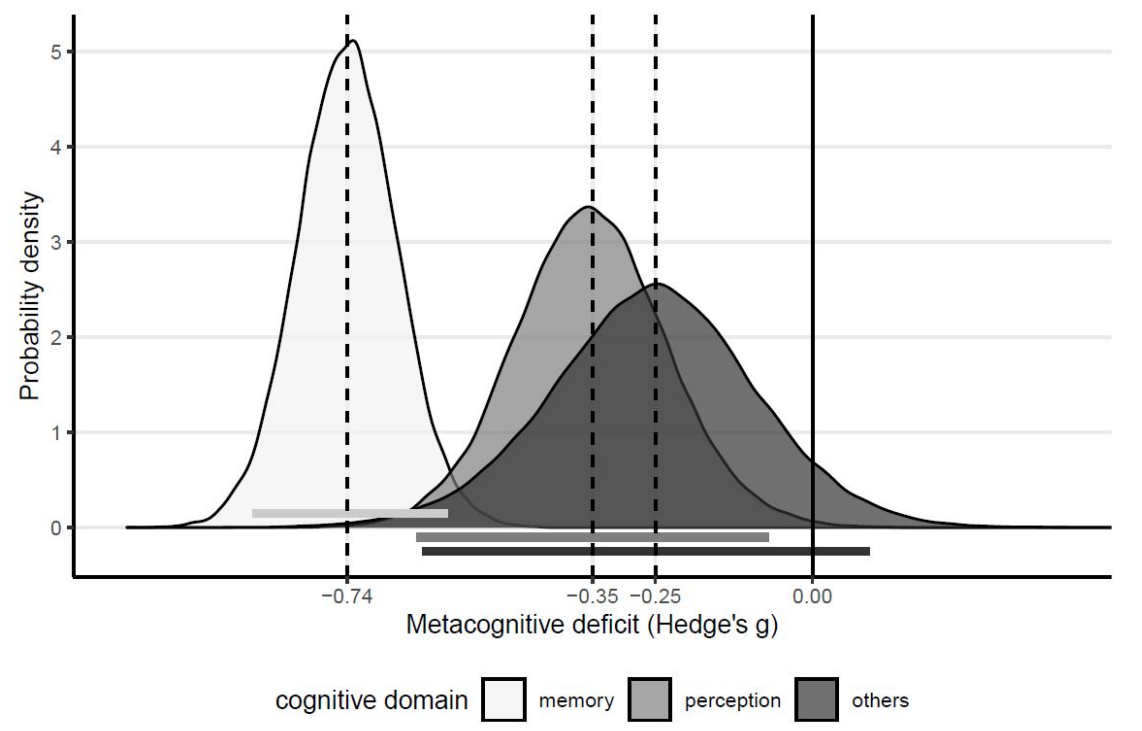

Figure 4: Posterior distributions of the metacognitive deficit (Hedge's g effect size) according to each cognitive domain. The vertical dashed lines represent mean values and the horizontal bars the $95 \% \mathrm{Crl}$. 
medRxiv preprint doi: https://doi.org/10.1101/2020.12.03.20243113; this version posted December 4, 2020. The copyright holder for this preprint (which was not certified by peer review) is the author/funder, who has granted medRxiv a license to display the preprint in

It is made available under a CC-BY-NC-ND 4.0 International license .

Finally, we performed further meta-regressions to explore how metacognitive deficits co-varied with the severity of positive and negative symptoms (PANSS equivalent scores) and antipsychotic dosage (chlorpromazine equivalent). Contrary to what we had predicted, none of these meta-regressions revealed conclusive evidence (SI).

\section{Risk of bias in selected studies}

A quality evaluation using the Newcastle-Ottawa Scale suggested that about half the studies had a relatively high risk of bias with scores < 5/9 (SI and Luchini et al., 2017). The shape of the funnel plot revealed no asymmetry (Egger's test: $z=-0.46, p=0.65$; Fig.5A and $\mathrm{SI}$ ), suggesting no clear publication bias. Plus, testing the right-skewness of the P-curve (Fig.5B) with Stouffer's method revealed that both the half ( $p$ 's $<0.025$ ) and full p-curves ( $p$ 's $<0.05$ ) were right-skewed with $p<.001$, suggesting that our study sample was not contaminated by $p$-hacking.
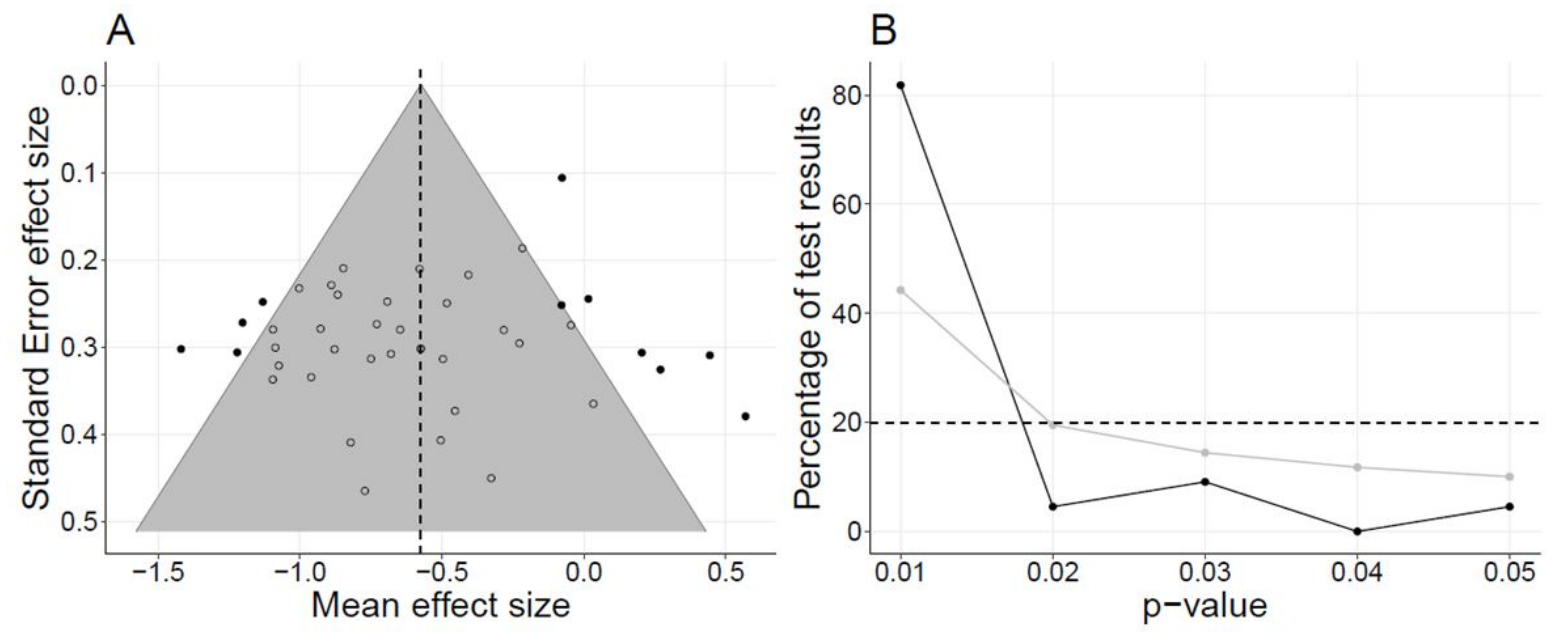

Figure 5: A: Funnel plot centered on the overall effect size. The vertical dashed line represents the global metacognitive deficit. The gray area represents the $95 \% \mathrm{Cl}$ of the overall effect size. Each dot represents a study, full dots represent outliers. B: Observed p-curve (black) and theoretical p-curve expected for low-powered (33\%) studies (gray). Horizontal dashed line: Expected uniform distribution for null effects.

\section{Discussion}

The present meta-analysis based on 43 studies and 2795 individuals aimed at synthesizing the literature on the calibration of confidence judgments among individuals with schizophrenia. At first sight, our findings confirmed a deficit in the calibration of confidence judgments in schizophrenia, but with high heterogeneity. The effect was of medium 
medRxiv preprint doi: https://doi.org/10.1101/2020.12.03.20243113; this version posted December 4,2020 . The copyright holder for this preprint (which was not certified by peer review) is the author/funder, who has granted medRxiv a license to display the preprint in It is made available under a CC-BY-NC-ND 4.0 International license.

magnitude, which is smaller than the large effects reported in prior meta-analyses regarding cognitive impairments (Schaefer et al., 2013). The leave-one-out sensitivity analysis confirmed this effect was robust to outliers. We found several sources for heterogeneity that we describe hereafter.

Because patients' first-order cognitive deficits risked to artificially inflate metacognitive deficits (Galvin et al., 2003), we hypothesized that metacognitive deficits would be reduced in studies equating first-order performance between groups. Results indicated strong evidence in favor of our hypothesis, as metacognitive deficits were twice smaller in studies controlling for first-order performance, most of them concerning the perceptual domain. In this subset of studies, assessing the presence of a metacognitive deficit revealed inconclusive evidence. By contrast, a correlation between cognitive and metacognitive deficits was found among non-controlled studies, indicating that first-order performance is a critical moderator of metacognition which should be controlled for when assessing metacognitive deficits in schizophrenia. We also explored possible differences in metacognitive deficits across cognitive domains (perception, memory, others), and found the most prominent deficits among memory studies. As such, this result is not sufficient to confirm the presence of a specific meta-memory deficit in schizophrenia, as all the memory studies but one did not control for differences in first-order performance between groups. Given that the magnitude of the meta-memory deficit we found is lower than the one of episodic verbal memory (range between -1.53 and -1.11 SD) (Gopal \& Variend, 2005; Heinrichs \& Zakzanis, 1998; Schaefer et al., 2013), arbitrating between the existence of a specific meta-memory deficit or the side effect of a non-controlled first-order factor will require the development of more robust experimental protocols. Of note, this meta-analysis did not examine the literature based on judgments of learning or feeling of knowing, which may reveal different patterns of results (Souchay et al., 2006).

Despite moderation analyses, heterogeneity remained high even after clustering studies according to performance matching and cognitive domains. This heterogeneity may be explained by the different diagnoses included in our selection of studies. The category of first episode of psychosis may be particularly problematic, as it included variable diagnoses (mania with psychosis, bipolar disorder with psychosis, depression with psychosis, delusional disorder, substance-induced psychotic disorder, psychosis not otherwise specified, acute and transient psychotic disorder, brief psychotic disorder). Heterogeneity may also come from the use of idiosyncratic first-order tasks (e.g., memory performance was quantified using recognition, source memory and spatial delayed response tasks) and 
medRxiv preprint doi: https://doi.org/10.1101/2020.12.03.20243113; this version posted December 4 , 2020. The copyright holder for this preprint (which was not certified by peer review) is the author/funder, who has granted medRxiv a license to display the preprint in It is made available under a CC-BY-NC-ND 4.0 International license.

confidence scales (e.g., ordinal vs. continuous scales, full vs. half scales, etc.). With this in mind, it will be important to use more systematic paradigms in the future.

Additional analyses evaluating how metacognitive deficits varied as a function of clinical scores (PANSS total, positive, negative) and antipsychotic dosage (chlorpromazine equivalent) revealed inconclusive evidence for correlation in each case. As we had no access to individual data, correlations were based on summary statistics extracted from each experimental group, which is clearly suboptimal. As with all meta-analyses, our findings are shaped and limited by selection and analytical methods, and the information made available to researchers in the studies selected for review. The scarcity of data prevented us from running planned analyses regarding the link between metacognitive performance and clinical/cognitive insight. Establishing this link is of crucial importance to validate confidence calibration as a valid empirical construct for clinical practice, and to refine current strategies to improve insight in schizophrenia. We encourage authors to share anonymized individual data similar to what is done for healthy controls (Rahnev et al., 2020) on a dedicated repository (https://osf.io/cfm5d/).

Our findings point to a number of areas for future research. First, few studies included in this meta-analysis measured mood, despite it being an important determinant of metacognition (Lin et al., 2019), with a bias toward underconfidence in depression (Hoven et al., 2019). No study included in this meta-analysis focused on the metacognition of executive function. Further studies are needed because meta-executive functions have been linked with attenuated psychosis syndrome (Koren et al., 2019). Further studies should also investigate whether the calibration of confidence judgments is associated with insight, relapse and psychosocial functioning before using it in clinical settings.

\section{Conclusion}

This is the first meta-analysis to examine the deficit in the calibration of confidence judgments in schizophrenia. Our results show that this deficit is inflated due to non-equated first-order performance, and varies across cognitive domains. Importantly, metacognitive deficits may also be overestimated in other psychiatric and neurological conditions involving cognitive impairments. Efforts should be made to develop experimental protocols accounting for lower first-order performance in schizophrenia before including calibration of confidence judgment as a cognitive dimension in neuropsychological batteries for clinical applications. 
medRxiv preprint doi: https://doi.org/10.1101/2020.12.03.20243113; this version posted December 4, 2020. The copyright holder for this preprint (which was not certified by peer review) is the author/funder, who has granted medRxiv a license to display the preprint in

It is made available under a CC-BY-NC-ND 4.0 International license .

\begin{tabular}{|c|c|c|c|c|c|c|c|c|}
\hline \multirow{2}{*}{ Study } & \multicolumn{2}{|c|}{ Sample size } & \multicolumn{2}{|c|}{ Age } & \multirow{2}{*}{$\begin{array}{c}\text { Matched } \\
\text { performance }\end{array}$} & \multirow{2}{*}{$\begin{array}{c}\text { Cognitive } \\
\text { domain }\end{array}$} & \multirow{2}{*}{ Metacognitive index } & \multirow{2}{*}{ NOS } \\
\hline & $\mathrm{SCZ}$ & $\mathrm{HC}$ & SCZ & $\mathrm{HC}$ & & & & \\
\hline Dietrichkeit 2020 & 39 & 20 & $34.72 \pm 8.68$ & $30.55 \pm 8.54$ & no & perception & $\mathrm{KCl}$ & 4.0 \\
\hline Jia 2020 & 38 & 38 & $22.6 \pm 8.3$ & $23 \pm 4.6$ & yes & perception & AUROC2 & 5.0 \\
\hline Jones 2020 & 215 & 151 & $41.72 \pm 11.64$ & $41.95 \pm 12.42$ & no & others & confidence gap & 5.0 \\
\hline Wright 2020 & 50 & 68 & $27.17 \pm 1.3$ & $25.7 \pm 6.6$ & yes & perception & M-ratio & 6.0 \\
\hline Alkan 2019 & 31 & 18 & $26.16 \pm 5.7$ & $24.06 \pm 4.87$ & yes & perception & M-ratio & 7.0 \\
\hline Berna 2019 & 10 & 10 & $36.3 \pm 7.5$ & $36.2 \pm 8.4$ & yes & memory & meta-d' - d' & 3.5 \\
\hline Faivre 2019 & 21 & 20 & $38.8 \pm 8.77$ & $42.6 \pm 3.35$ & yes & perception & M-ratio & 7.0 \\
\hline Gaweda 2019 & 33 & 33 & $35.82 \pm 11.22$ & $41.33 \pm 14.8$ & no & perception & false perception & 5.0 \\
\hline Davies 2018 & 31 & 18 & $26.16 \pm 5.69$ & $24.06 \pm 4.87$ & yes & perception & M-ratio & 7.0 \\
\hline Gaweda 2018 & 25 & 33 & $20.36 \pm 2.16$ & $20.27 \pm 2.11$ & no & memory & $\mathrm{KCl}$ & 5.7 \\
\hline Mayer 2018 & 24 & 24 & $40.67 \pm 11.65$ & $38.88 \pm 9.66$ & no & memory & false memories & 5.5 \\
\hline Pinkham 2018 & 31 & 32 & $35.65 \pm 7.52$ & $35.41 \pm 7.07$ & no & others & AUROC2 & 3.5 \\
\hline Charles 2017 & 13 & 13 & $28.8 \pm 5.9$ & $28.8 \pm 4.7$ & no & perception & meta-d' & 5.0 \\
\hline Powers 2017 & 15 & 15 & $39.4 \pm 13.47$ & $46.07 \pm 12.96$ & yes & perception & M-ratio & 5.5 \\
\hline Powers 2017 & 15 & 15 & $39.4 \pm 13.47$ & $46.07 \pm 12.96$ & yes & perception & M-ratio & 5.5 \\
\hline Powers 2017 & 14 & 15 & $38.29 \pm 14.4$ & $40.53 \pm 13.04$ & yes & perception & M-ratio & 5.5 \\
\hline Powers 2017 & 14 & 15 & $38.29 \pm 14.4$ & $40.53 \pm 13.04$ & yes & perception & M-ratio & 5.5 \\
\hline Balzan 2016 & 25 & 50 & $39.96 \pm 10.04$ & $42.8 \pm 15.46$ & no & memory & confidence in errors & 4.0 \\
\hline Eifler 2015 & 29 & 25 & $37.22 \pm 9.68$ & $38.12 \pm 10.72$ & no & memory & confidence gap & 4.0 \\
\hline Eisecher 2015 & 21 & 38 & $26.52 \pm 5.57$ & $25.08 \pm 6.55$ & no & memory & confidence gap & 3.5 \\
\hline Gaweda 2015 & 13 & 17 & $22.08 \pm 1.93$ & $23.59 \pm 1.87$ & no & memory & $\mathrm{KCl}$ & 4.0 \\
\hline Gaweda 2015 & 13 & 17 & $22.08 \pm 1.93$ & $23.59 \pm 1.87$ & no & memory & $\mathrm{KCl}$ & 4.0 \\
\hline Gaweda 2015 & 10 & 10 & $53.9 \pm 3.21$ & $57.4 \pm 3.72$ & no & memory & $\mathrm{KCl}$ & 4.0 \\
\hline Gaweda 2015 & 10 & 10 & $53.9 \pm 3.21$ & $57.4 \pm 3.72$ & no & memory & $\mathrm{KCl}$ & 4.0 \\
\hline Akdogan 2014 & 23 & 23 & $38 \pm 8$ & $37.5 \pm 7.2$ & no & memory & gamma correlation & 3.3 \\
\hline Mayer 2014 & 31 & 28 & $40.23 \pm 9.1$ & $37.89 \pm 8.35$ & no & memory & false memories & 4.0 \\
\hline Moritz 2014 & 55 & 45 & $38.22 \pm 8.61$ & $37.24 \pm 13.93$ & no & perception & $\mathrm{KCl}$ & 4.5 \\
\hline Gaweda 2013 & 54 & 34 & $35.17 \pm 10.43$ & $33.21 \pm 11.33$ & no & memory & $\mathrm{KCl}$ & 4.5 \\
\hline Peters 2013 & 27 & 24 & $37.96 \pm 12.86$ & $34.21 \pm 11.33$ & no & memory & $\mathrm{KCl}$ & 4.5 \\
\hline Gaweda 2012 & 32 & 32 & $32.81 \pm 8.36$ & $31.78 \pm 11.67$ & no & memory & $\mathrm{KCl}$ & 4.7 \\
\hline Kother 2012 & 76 & 30 & $34.26 \pm 11.41$ & $32.97 \pm 10.88$ & no & others & $\mathrm{KCl}$ & 4.0 \\
\hline Mayer 2012 & 28 & 29 & $38.32 \pm 9.29$ & $37.28 \pm 8.41$ & no & memory & false memories & 5.0 \\
\hline Metcalfe 2012 & 22 & 20 & $42.3 \pm 11.1$ & $38.1 \pm 11.3$ & no & others & $\begin{array}{l}\text { correlation perf- } \\
\text { confidence }\end{array}$ & 5.0 \\
\hline Moritz 2012 & 23 & 29 & $35.17 \pm 11.12$ & $34.24 \pm 16.14$ & no & others & $\mathrm{KCl}$ & 4.5 \\
\hline Peters 2012 & 47 & 47 & $35.72 \pm 11.63$ & $36.87 \pm 11.89$ & no & memory & $\mathrm{KCl}$ & 5.0 \\
\hline Bhatt 2010 & 25 & 20 & $47 \pm 8.65$ & $44.5 \pm 8.81$ & no & memory & $\mathrm{KCl}$ & 2.0 \\
\hline Kim 2010 & 12 & 13 & $40.2 \pm 10.23$ & $40.4 \pm 9.34$ & no & memory & false memories & 4.5 \\
\hline Moritz 2008 & 68 & 25 & $33.94 \pm 10.45$ & $32.04 \pm 10.23$ & no & memory & confidence gap & 4.0 \\
\hline Kircher 2007 & 27 & 19 & $32.8 \pm 11.4$ & $33.4 \pm 13.4$ & no & memory & $\begin{array}{l}\text { correlation perf- } \\
\text { confidence }\end{array}$ & 5.0 \\
\hline Peters 2007 & 23 & 20 & $36.3 \pm 13.13$ & $35.2 \pm 9.71$ & no & memory & confidence gap & 6.0 \\
\hline Moritz_a 2006 & 31 & 61 & $33.77 \pm 9.9$ & $31.05 \pm 8.75$ & no & memory & confidence gap & 4.5 \\
\hline Moritz_b 2006 & 30 & 15 & $24.73 \pm 8.73$ & $24.8 \pm 8.99$ & no & memory & confidence gap & 3.5 \\
\hline Moritz_c 2006 & 35 & 34 & $36.29 \pm 11.34$ & $34.29 \pm 11.38$ & no & memory & $\mathrm{KCl}$ & 4.0 \\
\hline Moritz 2005 & 30 & 17 & $37.3 \pm 10.16$ & $37.67 \pm 12.47$ & no & memory & $\mathrm{KCl}$ & 4.5 \\
\hline Moritz 2004 & 20 & 20 & $33.2 \pm 9.28$ & $29.2 \pm 12.51$ & no & memory & $\mathrm{KCl}$ & 4.5 \\
\hline Moritz 2003 & 30 & 22 & $31.08 \pm 8.3$ & $27 \pm 10.7$ & no & memory & confidence gap & 4.0 \\
\hline Bacon 2001 & 19 & 19 & $31.7 \pm 8.4$ & $30.7 \pm 8.2$ & no & memory & confidence gap & 3.5 \\
\hline
\end{tabular}

Table 1: study characteristics. $\mathrm{KCl}$ : knowledge corruption index; AUROC2: area under the type 2 receiver operating characteristic curve. 
medRxiv preprint doi: https://doi.org/10.1101/2020.12.03.20243113; this version posted December 4 , 2020. The copyright holder for this preprint (which was not certified by peer review) is the author/funder, who has granted medRxiv a license to display the preprint in It is made available under a CC-BY-NC-ND 4.0 International license.

\section{References}

Akdogan, E., Izaute, M., \& Bacon, E. (2014). Preserved strategic grain-size regulation in memory reporting in patients with schizophrenia. Biological Psychiatry, 76(2), 154-159.

https://doi.org/10.1016/j.biopsych.2013.09.004https://doi.org/10.1016/j.concog.2019 .102847

Alkan, E., Davies, G., Greenwood, K., \& Evans, S. L. H. (2019). Brain Structural Correlates of Metacognition in First-Episode Psychosis. Schizophrenia Bulletin. https://doi.org/10.1093/schbul/sbz116

Arnon-Ribenfeld, N., Hasson-Ohayon, I., Lavidor, M., Atzil-Slonim, D., \& Lysaker, P. H. (2017). The association between metacognitive abilities and outcome measures among people with schizophrenia: A meta-analysis. European Psychiatry : The Journal of the Association of European Psychiatrists, 46, 33-41. https://doi.org/10.1016/j.eurpsy.2017.08.002

Bacon, E., Danion, J.-M., Kauffmann-Muller, F., \& Bruant, A. (2001). Consciousness in schizophrenia: A metacognitive approach to semantic memory. Consciousness and Cognition, 10(4), 473-484. https://doi.org/10.1006/ccog.2001.0519

Balzan, R. P., Woodward, T. S., Delfabbro, P., \& Moritz, S. (2016). Overconfidence across the psychosis continuum: A calibration approach. Cognitive Neuropsychiatry, 21(6), 510-524. https://doi.org/10.1080/13546805.2016.1240072

Berna, F., Zou, F., Danion, J.-M., \& Kwok, S. C. (2019). Overconfidence in false autobiographical memories in patients with schizophrenia. Psychiatry Research, 279, 374-375. https://doi.org/10.1016/j.psychres.2018.12.063

Bhatt, R., Laws, K. R., \& McKenna, P. J. (2010). False memory in schizophrenia patients with and without delusions. Psychiatry Research, 178(2), 260-265. https://doi.org/10.1016/j.psychres.2009.02.006

Borenstein, M., Hedges, L. V., Higgins, J. P. T., \& Rothstein, H. R. (Eds.). (2010). Introduction to meta-analysis (Reprinted). Wiley.

Bürkner, P.-C. (2017). brms: An R Package for Bayesian Multilevel Models Using Stan. Journal of Statistical Software, 80(1). https://doi.org/10.18637/jss.v080.i01

Card, N. A., \& Little, T. D. (2016). Applied meta-analysis for social science research (Paperback edition). The Guilford Press.

Carpenter, B., Gelman, A., Hoffman, M. D., Lee, D., Goodrich, B., Betancourt, M., Brubaker, M., Guo, J., Li, P., \& Riddell, A. (2017). Stan: A Probabilistic Programming Language. Journal of Statistical Software, 76(1). https://doi.org/10.18637/jss.v076.i01

Charles, L., Gaillard, R., Amado, I., Krebs, M.-O., Bendjemaa, N., \& Dehaene, S. (2017). Conscious and unconscious performance monitoring: Evidence from patients with schizophrenia. Neurolmage, 144, 153-163. https://doi.org/10.1016/j.neuroimage.2016.09.056

David, A. S., Bedford, N., Wiffen, B., \& Gilleen, J. (2012). Failures of metacognition and lack of insight in neuropsychiatric disorders. Philosophical Transactions of the Royal Society B: Biological Sciences, 367(1594), 1379-1390. https://doi.org/10.1098/rstb.2012.0002

Davies, G., \& Greenwood, K. (2020). A meta-analytic review of the relationship between neurocognition, metacognition and functional outcome in schizophrenia. Journal of Mental Health, 29(5), 496-505. https://doi.org/10.1080/09638237.2018.1521930

Davies, G., Rae, C. L., Garfinkel, S. N., Seth, A. K., Medford, N., Critchley, H. D., \& Greenwood, K. (2018). Impairment of perceptual metacognitive accuracy and reduced prefrontal grey matter volume in first-episode psychosis. Cognitive 
medRxiv preprint doi: https://doi.org/10.1101/2020.12.03.20243113; this version posted December 4, 2020. The copyright holder for this preprint (which was not certified by peer review) is the author/funder, who has granted medRxiv a license to display the preprint in It is made available under a CC-BY-NC-ND 4.0 International license .

Neuropsychiatry, 23(3), 165-179. https://doi.org/10.1080/13546805.2018.1444597

Dietrichkeit, M., Grzella, K., Nagel, M., \& Moritz, S. (2020). Using virtual reality to explore differences in memory biases and cognitive insight in people with psychosis and healthy controls. Psychiatry Research, 285, 112787-112787.

https://doi.org/10.1016/j.psychres.2020.112787

Eifler, S., Rausch, F., Schirmbeck, F., Veckenstedt, R., Mier, D., Esslinger, C., Englisch, S., Meyer-Lindenberg, A., Kirsch, P., \& Zink, M. (2015). Metamemory in schizophrenia: Retrospective confidence ratings interact with neurocognitive deficits. Psychiatry Research, 225(3), 596-603. https://doi.org/10.1016/j.psychres.2014.11.040

Eisenacher, S., Rausch, F., Ainser, F., Mier, D., Veckenstedt, R., Schirmbeck, F., Lewien, A., Englisch, S., Andreou, C., Moritz, S., Meyer-Lindenberg, A., Kirsch, P., \& Zink, M. (2015). Investigation of metamemory functioning in the at-risk mental state for psychosis. Psychological Medicine, 45(15), 3329-3340. https://doi.org/10.1017/S0033291715001373

Faivre, N. (2019). Confidence in Perceptual Decision-Making Is Preserved in Schizophrenia. Confidence in Perceptual Decision-Making Is Preserved in Schizophrenia.

Faivre, Nathan, Roger, M., Pereira, M., de Gardelle, V., Vergnaud, J.-C., Passerieux, C., \& Roux, P. (2019). Confidence in perceptual decision-making is preserved in schizophrenia [Preprint]. Psychiatry and Clinical Psychology. https://doi.org/10.1101/2019.12.15.19014969

Faivre, Nathan, Roger, M., Pereira, M., de Gardelle, V., Vergnaud, J.-C., Passerieux, C., \& Roux, P. (2020). Confidence in visual motion discrimination is preserved in individuals with schizophrenia. Psychiatry and Clinical Neurosciences. https://doi.org/10.1503/jpn.200022

Fleming, S. M., \& Lau, H. C. (2014). How to measure metacognition. Frontiers in Human Neuroscience, 8. https://doi.org/10.3389/fnhum.2014.00443

Galvin, S. J., Podd, J. V., Drga, V., \& Whitmore, J. (2003). Type 2 tasks in the theory of signal detectability: Discrimination between correct and incorrect decisions. Psychonomic Bulletin \& Review, 10(4), 843-876. https://doi.org/10.3758/BF03196546

Gaweda, L. (2015a). Does aging affect source monitoring and cognitive confidence in schizophrenia? Preliminary results. Psychiatry Research, 228(3), 936-940. https://doi.org/10.1016/j.psychres.2015.06.024

Gaweda, L. (2015b). Does aging affect source monitoring and cognitive confidence in schizophrenia? Preliminary results. Psychiatry Research, 228(3), 936-940. https://doi.org/10.1016/j.psychres.2015.06.024

Gawęda, Ł., Li, E., Lavoie, S., Whitford, T. J., Moritz, S., \& Nelson, B. (2018). Impaired action self-monitoring and cognitive confidence among ultra-high risk for psychosis and first-episode psychosis patients. European Psychiatry, 47, 67-75. https://doi.org/10.1016/j.eurpsy.2017.09.003

Gaweda, L., \& Moritz, S. (2019a). The role of expectancies and emotional load in false auditory perceptions among patients with schizophrenia spectrum disorders. European Archives of Psychiatry and Clinical Neuroscience. https://doi.org/10.1007/s00406-019-01065-2

Gaweda, L., \& Moritz, S. (2019b). The role of expectancies and emotional load in false auditory perceptions among patients with schizophrenia spectrum disorders. European Archives of Psychiatry and Clinical Neuroscience. https://doi.org/10.1007/s00406-019-01065-2

Gaweda, Ł., Moritz, S., \& Kokoszka, A. (2012). Impaired discrimination between imagined and performed actions in schizophrenia. Psychiatry Research, 195(1-2), 1-8. 
medRxiv preprint doi: https://doi.org/10.1101/2020.12.03.20243113; this version posted December 4, 2020. The copyright holder for this preprint (which was not certified by peer review) is the author/funder, who has granted medRxiv a license to display the preprint in

It is made available under a CC-BY-NC-ND 4.0 International license .

https://doi.org/10.1016/j.psychres.2011.07.035

Gaweda, Ł., Woodward, T. S., Moritz, S., \& Kokoszka, A. (2013). Impaired action self-monitoring in schizophrenia patients with auditory hallucinations. Schizophrenia Research, 144(1-3), 72-79. https://doi.org/10.1016/j.schres.2012.12.003

Gopal, Y. V., \& Variend, H. (2005). First-episode schizophrenia: Review of cognitive deficits and cognitive remediation. Advances in Psychiatric Treatment, 11(1), 38-44. https://doi.org/10.1192/apt.11.1.38

Harrer, M., Cuijpers, P., \& Ebert, D. (2019). Doing Meta-Analysis in R. https://doi.org/10.5281/ZENODO.2551803

Hasson-Ohayon, I., Goldzweig, G., Lavi-Rotenberg, A., Luther, L., \& Lysaker, P. H. (2018). The centrality of cognitive symptoms and metacognition within the interacting network of symptoms, neurocognition, social cognition and metacognition in schizophrenia. Schizophrenia Research, 202, 260-266. https://doi.org/10.1016/j.schres.2018.07.007

Heinrichs, R. W., \& Zakzanis, K. K. (1998). Neurocognitive deficit in schizophrenia: A quantitative review of the evidence. Neuropsychology, 12(3), 426-445. https://doi.org/10.1037/0894-4105.12.3.426

Higgins, J. P. T., \& Thompson, S. G. (2002). Quantifying heterogeneity in a meta-analysis. Statistics in Medicine, 21(11), 1539-1558. https://doi.org/10.1002/sim.1186

Hoven, M., Lebreton, M., Engelmann, J. B., Denys, D., Luigjes, J., \& van Holst, R. J. (2019). Abnormalities of confidence in psychiatry: An overview and future perspectives. Translational Psychiatry, 9(1), 268. https://doi.org/10.1038/s41398-019-0602-7

Jia, W., Zhu, H., Ni, Y., Su, J., Xu, R., Jia, H., \& Wan, X. (2020). Disruptions of frontoparietal control network and default mode network linking the metacognitive deficits with clinical symptoms in schizophrenia. Human Brain Mapping, 41(6), 1445-1458. https://doi.org/10.1002/hbm.24887

Jones, M. T., Deckler, E., Laurrari, C., Jarskog, L. F., Penn, D. L., Pinkham, A. E., \& Harvey, P. D. (2020). Confidence, performance, and accuracy of self-assessment of social cognition: A comparison of schizophrenia patients and healthy controls. Schizophrenia Research. Cognition, 19, 2-2. https://doi.org/10.1016/j.scog.2019.01.002

Kim, J., Matthews, N. L., \& Park, S. (2010). An event-related fMRI study of phonological verbal working memory in schizophrenia. PLOS ONE, 5(8). https://doi.org/10.1371/journal.pone.0012068

Kircher, T. T. J., Koch, K., Stottmeister, F., \& Durst, V. (2007). Metacognition and reflexivity in patients with schizophrenia. Psychopathology, 40(4), 254-260. https://doi.org/10.1159/000101730

Koo, T. K., \& Li, M. Y. (2016). A Guideline of Selecting and Reporting Intraclass Correlation Coefficients for Reliability Research. Journal of Chiropractic Medicine, 15(2), 155-163. https://doi.org/10.1016/j.jcm.2016.02.012

Koren, D., Scheyer, R., Stern, Y., Adres, M., Reznik, N., Apter, A., \& Seidman, L. J. (2019). Metacognition strengthens the association between neurocognition and attenuated psychosis syndrome: Preliminary evidence from a pilot study among treatment-seeking versus healthy adolescents. Schizophrenia Research, 210, 207-214. https://doi.org/10.1016/j.schres.2018.12.036

Koren, D., Seidman, L. J., Goldsmith, M., \& Harvey, P. D. (2006). Real-world cognitive-And metacognitive-Dysfunction in schizophrenia: A new approach for measuring (and remediating) more 'right stuff'. Schizophrenia Bulletin, 32(2), 310-326. https://doi.org/10.1093/schbul/sbj035

Kother, U., Lincoln, T. M., \& Moritz, S. (2018). Emotion perception and overconfidence in 
medRxiv preprint doi: https://doi.org/10.1101/2020.12.03.20243113; this version posted December 4, 2020. The copyright holder for this preprint (which was not certified by peer review) is the author/funder, who has granted medRxiv a license to display the preprint in

It is made available under a CC-BY-NC-ND 4.0 International license.

errors under stress in psychosis. Psychiatry Research, 270, 981-991.

https://doi.org/10.1016/j.psychres.2018.03.044

Kother, U., Veckenstedt, R., Vitzthum, F., Roesch-Ely, D., Pfueller, U., Scheu, F., \& Moritz, S. (2012a). 'Don't give me that look'-Overconfidence in false mental state perception in schizophrenia. Psychiatry Research, 196(1), 1-8. https://doi.org/10.1016/j.psychres.2012.03.004

Kother, U., Veckenstedt, R., Vitzthum, F., Roesch-Ely, D., Pfueller, U., Scheu, F., \& Moritz, S. (2012b). 'Don't give me that look'-Overconfidence in false mental state perception in schizophrenia. Psychiatry Research, 196(1), 1-8. https://doi.org/10.1016/j.psychres.2012.03.004

Leucht, S., Rothe, P., Davis, J. M., \& Engel, R. R. (2013). Equipercentile linking of the BPRS and the PANSS. European Neuropsychopharmacology, 23(8), 956-959. https://doi.org/10.1016/j.euroneuro.2012.11.004

Levitt, H. (1971). Transformed Up-Down Methods in Psychoacoustics. The Journal of the Acoustical Society of America, 49(2B), 467-477. https://doi.org/10.1121/1.1912375

Lin, X., Lu, D., Huang, Z., Chen, W., Luo, X., \& Zhu, Y. (2019). The associations between subjective and objective cognitive functioning across manic or hypomanic, depressed, and euthymic states in Chinese bipolar patients. Journal of Affective Disorders, 249, 73-81. https://doi.org/10.1016/j.jad.2019.02.025

Luchini, C., Stubbs, B., Solmi, M., \& Veronese, N. (2017). Assessing the quality of studies in meta-analyses: Advantages and limitations of the Newcastle Ottawa Scale. World Journal of Meta-Analysis, 5(4), 80. https://doi.org/10.13105/wjma.v5.i4.80

Lüdecke, D. (2018). Esc: Effect Size Computation For Meta Analysis. Zenodo. https://doi.org/10.5281/ZENODO.1249218

Maniscalco, B., \& Lau, H. (2012). A signal detection theoretic approach for estimating metacognitive sensitivity from confidence ratings. Consciousness and Cognition, 21(1), 422-430. https://doi.org/10.1016/j.concog.2011.09.021

Mayer, J S, Kim, J., \& Park, S. (2014). Failure to benefit from target novelty during encoding contributes to working memory deficits in schizophrenia. Cognitive Neuropsychiatry, 19(3), 268-279. https://doi.org/10.1080/13546805.2013.854199

Mayer, J S, \& Park, S. (2012). Working memory encoding and false memory in schizophrenia and bipolar disorder in a spatial delayed response task. Journal of Abnormal Psychology, 121(3), 784-794. https://doi.org/10.1037/a0028836

Mayer, Jutta S, Stablein, M., Oertel-Knochel, V., \& Fiebach, C. J. (2018). Functional Dissociation of Confident and Not-Confident Errors in the Spatial Delayed Response Task Demonstrates Impairments in Working Memory Encoding and Maintenance in Schizophrenia. Frontiers in Psychiatry, 9, 202-202. https://doi.org/10.3389/fpsyt.2018.00202

McLeod, H. J., Gumley, A. I., MacBeth, A., Schwannauer, M., \& Lysaker, P. H. (2014). Metacognitive functioning predicts positive and negative symptoms over 12 months in first episode psychosis. Journal of Psychiatric Research, 54, 109-115. https://doi.org/10.1016/j.jpsychires.2014.03.018

Metcalfe, J., van Snellenberg, J. X., DeRosse, P., Balsam, P., \& Malhotra, A. K. (2012). Judgements of agency in schizophrenia: An impairment in autonoetic metacognition. Philosophical Transactions of the Royal Society B: Biological Sciences, 367(1594), 1391-1400. https://doi.org/10.1098/rstb.2012.0006

Moher, D., Liberati, A., Tetzlaff, J., Altman, D. G., \& The PRISMA Group. (2009). Preferred Reporting Items for Systematic Reviews and Meta-Analyses: The PRISMA Statement. PLoS Medicine, 6(7), e1000097. https://doi.org/10.1371/journal.pmed.1000097

Moritz, S., Ramdani, N., Klass, H., Andreou, C., Jungclaussen, D., Eifler, S., Englisch, S., 
medRxiv preprint doi: https://doi.org/10.1101/2020.12.03.20243113; this version posted December 4, 2020. The copyright holder for this preprint (which was not certified by peer review) is the author/funder, who has granted medRxiv a license to display the preprint in It is made available under a CC-BY-NC-ND 4.0 International license .

Schirmbeck, F., \& Zink, M. (2014). Overconfidence in incorrect perceptual judgments in patients with schizophrenia. Schizophrenia Research: Cognition, 1(4), 165-170. https://doi.org/10.1016/j.scog.2014.09.003

Moritz, S., \& Woodward, T. S. (2006). The contribution of metamemory deficits to schizophrenia. Journal of Abnormal Psychology, 115(1), 15-25. https://doi.org/10.1037/0021-843X.15.1.15

Moritz, S., Woodward, T. S., \& Chen, E. (2006). Investigation of metamemory dysfunctions in first-episode schizophrenia. Schizophrenia Research, 81(2-3), 247-252. https://doi.org/10.1016/j.schres.2005.09.004

Moritz, S., Woodward, T. S., Cuttler, C., Whitman, J. C., \& Watson, J. M. (2004). False Memories in Schizophrenia. Neuropsychology, 18(2), 276-283. https://doi.org/10.1037/0894-4105.18.2.276

Moritz, S., Woodward, T. S., Jelinek, L., \& Klinge, R. (2008). Memory and metamemory in schizophrenia: A liberal acceptance account of psychosis. Psychological Medicine, 38(6), 825-832. https://doi.org/10.1017/S0033291707002553

Moritz, S., Woodward, T. S., \& Rodriguez-Raecke, R. (2006). Patients with schizophrenia do not produce more false memories than controls but are more confident in them. Psychological Medicine, 36(5), 659-667. https://doi.org/10.1017/S0033291706007252

Moritz, S., Woodward, T. S., \& Ruff, C. C. (2003). Source monitoring and memory confidence in schizophrenia. Psychological Medicine, 33(1), 131-139. https://doi.org/10.1017/S0033291702006852

Moritz, S., Woodward, T. S., Whitman, J. C., \& Cuttler, C. (2005). Confidence in errors as a possible basis for delusions in schizophrenia. Journal of Nervous and Mental Disease, 193(1), 9-16. https://doi.org/10.1097/01.nmd.0000149213.10692.00

Moritz, S., Woznica, A., Andreou, C., \& Köther, U. (2012a). Response confidence for emotion perception in schizophrenia using a Continuous Facial Sequence Task. Psychiatry Research, 200(2-3), 202-207. https://doi.org/10.1016/j.psychres.2012.07.007

Moritz, S., Woznica, A., Andreou, C., \& Köther, U. (2012b). Response confidence for emotion perception in schizophrenia using a Continuous Facial Sequence Task. Psychiatry Research, 200(2-3), 202-207. https://doi.org/10.1016/j.psychres.2012.07.007

Peters, M J V, Cima, M. J., Smeets, T., De Vos, M., Jelicic, M., \& Merckelbach, H. (2007). Did I say that word or did you? Executive dysfunctions in schizophrenic patients affect memory efficiency, but not source attributions. Cognitive Neuropsychiatry, 12(5), 391-411. https://doi.org/10.1080/13546800701470145

Peters, M J V, Hauschildt, M., Moritz, S., \& Jelinek, L. (2013). Impact of emotionality on memory and meta-memory in schizophrenia using video sequences. Journal of Behavior Therapy and Experimental Psychiatry, 44(1), 77-83. https://doi.org/10.1016/j.jbtep.2012.07.003

Peters, Maarten J V, Engel, M., Hauschildt, M., Moritz, S., Jelinek, L., \& Otgaar, H. (2012). Investigating the Corrective Effect of Forewarning On Memory and Meta-Memory Deficits in Schizophrenia Patients. Journal of Experimental Psychopathology, 3(4), 673-687. https://doi.org/10.5127/jep.022011

Pinkham, A. E., Klein, H. S., Hardaway, G. B., Kemp, K. C., \& Harvey, P. D. (2018a). Neural correlates of social cognitive introspective accuracy in schizophrenia. Schizophrenia Research, 202, 166-172. https://doi.org/10.1016/j.schres.2018.07.001

Pinkham, A. E., Klein, H. S., Hardaway, G. B., Kemp, K. C., \& Harvey, P. D. (2018b). Neural correlates of social cognitive introspective accuracy in schizophrenia. 
medRxiv preprint doi: https://doi.org/10.1101/2020.12.03.20243113; this version posted December 4, 2020. The copyright holder for this preprint (which was not certified by peer review) is the author/funder, who has granted medRxiv a license to display the preprint in It is made available under a CC-BY-NC-ND 4.0 International license .

Schizophrenia Research, 202, 166-172.

https://doi.org/10.1016/j.schres.2018.07.001

Powers, A. R., Mathys, C., \& Corlett, P. R. (2017a). Pavlovian conditioning-induced hallucinations result from overweighting of perceptual priors. Science, 357(6351), 596-600. https://doi.org/10.1126/science.aan3458

Powers, A. R., Mathys, C., \& Corlett, P. R. (2017b). Pavlovian conditioning-induced hallucinations result from overweighting of perceptual priors. Science, 357(6351), 596-600. https://doi.org/10.1126/science.aan3458

Rahnev, D., Desender, K., Lee, A. L. F., Adler, W. T., Aguilar-Lleyda, D., Akdoğan, B., Arbuzova, P., Atlas, L. Y., Balcı, F., Bang, J. W., Bègue, I., Birney, D. P., Brady, T. F., Calder-Travis, J., Chetverikov, A., Clark, T. K., Davranche, K., Denison, R. N., Dildine, T. C., ... Zylberberg, A. (2020). The Confidence Database. Nature Human Behaviour, 4(3), 317-325. https://doi.org/10.1038/s41562-019-0813-1

Schaefer, J., Giangrande, E., Weinberger, D. R., \& Dickinson, D. (2013). The global cognitive impairment in schizophrenia: Consistent over decades and around the world. Schizophrenia Research, 150(1), 42-50. https://doi.org/10.1016/j.schres.2013.07.009

Semerari, A., Carcione, A., Dimaggio, G., Falcone, M., Nicolò, G., Procacci, M., \& Alleva, G. (2003). How to evaluate metacognitive functioning in psychotherapy? The metacognition assessment scale and its applications: Assessing Metacognitive Functions in Psychotherapy. Clinical Psychology \& Psychotherapy, 10(4), 238-261. https://doi.org/10.1002/cpp.362

Simonsohn, U., Nelson, L. D., \& Simmons, J. P. (2014). P-curve: A key to the file-drawer. Journal of Experimental Psychology: General, 143(2), 534-547. https://doi.org/10.1037/a0033242

Souchay, C., Bacon, E., \& Danion, J. M. (2006). Metamemory in schizophrenia: An exploration of the feeling-of-knowing state. Journal of Clinical and Experimental Neuropsychology, 28(5), 828-840. https://doi.org/10.1080/13803390591000846

Sterne, J. A. C., \& Harbord, R. M. (2004). Funnel Plots in Meta-analysis. The Stata Journal: Promoting Communications on Statistics and Stata, 4(2), 127-141. https://doi.org/10.1177/1536867X0400400204

van Erp, T. G. M., Preda, A., Nguyen, D., Faziola, L., Turner, J., Bustillo, J., Belger, A., Lim, K. O., McEwen, S., Voyvodic, J., Mathalon, D. H., Ford, J., Potkin, S. G., \& Fbirn. (2014). Converting positive and negative symptom scores between PANSS and SAPS/SANS. Schizophrenia Research, 152(1), 289-294. https://doi.org/10.1016/j.schres.2013.11.013

Vohs, J. L., Lysaker, P. H., Francis, M. M., Hamm, J., Buck, K. D., Olesek, K., Outcalt, J., Dimaggio, G., Leonhardt, B., Liffick, E., Mehdiyoun, N., \& Breier, A. (2014). Metacognition, social cognition, and symptoms in patients with first episode and prolonged psychoses. Schizophrenia Research, 153(1-3), 54-59. https://doi.org/10.1016/j.schres.2014.01.012

Wagenmakers, E.-J., Marsman, M., Jamil, T., Ly, A., Verhagen, J., Love, J., Selker, R., Gronau, Q. F., Šmíra, M., Epskamp, S., Matzke, D., Rouder, J. N., \& Morey, R. D. (2018). Bayesian inference for psychology. Part I: Theoretical advantages and practical ramifications. Psychonomic Bulletin \& Review, 25(1), 35-57. https://doi.org/10.3758/s13423-017-1343-3

Wright, A., Nelson, B., Fowler, D., \& Greenwood, K. (2020). Perceptual biases and metacognition and their association with anomalous self experiences in first episode psychosis. Consciousness and Cognition, 77, 102847-102847. https://doi.org/10.1016/j.concog.2019.102847 